\title{
Rho GTPase-Activating Protein 26
}

National Cancer Institute

\section{Source}

National Cancer Institute. Rho GTPase-Activating Protein 26. NCI Thesaurus. Code C97508.

Rho GT Pase-activating protein 26 ( $814 \mathrm{aa}, \sim 92 \mathrm{kDa}$ ) is encoded by the human ARHGAP26 gene. This protein plays a role in the regulation of transforming protein RhoA and cell division control protein 42 homolog-mediated signaling. 